\author{
석탄화력발전 해외수출의 경제적 파급효과 분석 \\ 진세준 · 유승훈 \\ 한국해양과학기술원 해양정책연구소 해양환경·산업연구실, 서울과학기술대학교 에너지환경대학원 에너지정책학과 \\ (2013년 2월 14일 접수, 2013년 3월 15일 수정, 2013년 3월 15일 채택)
}

\title{
The Effects of Coal Thermal Power Plant Exports on the National Economy
}

\author{
Jin, Se-Jun and Yoo, Seung-Hoon ${ }^{\dagger}$
}

Environment and Economics Assessment Section, Ocean Policy Institute, KIOST and Department of Energy

Policy, Graduate School of Energy \& Environment, Seoul National University of Science \& Technology

(Received 14 February 2013, Revised 15 March 2013, Accepted 15 March 2013)

요 약

국내 전력시장은 포화상태로 해외시장 개척을 통해 국내 전력산업의 한계를 극복하기 위한 방안을 모색하려 한다. 해외 전력시장에서 우리나라의 전력산업이 경쟁력을 갖추고 지속적인 성장을 추구하기 위해서 해외시장에 적극적인 투자를 추진하고 있다. 이에 본 논문에서는 여러 전력산업에서 가장 대표 적인 화력발전 중 석탄화력발전의 해외수출이 국내 경제에 미치는 파급효과를 분석하고자 한다. 특히 경제적 파급효과로 생산유발효과, 부가가치 유발효과, 취업유발효과의 3 가지를 분석하되, 수요유도형 모형을 적용한 분석 결과를 제시한다. 한국은행 산업연관표 통합소분류 기준 168 부문 중에서 17 개 부문을 석탄화력발전 관련 부문이라 정의한 후, 석탄화력발전 관련 산업을 중심에 놓고 이를 외생화하 여 분석한다. 과거 석탄화력발전 수출 사례를 적용하여 석탄화력발전 해외수출의 경제적 파급효과를 분석한다. 석탄화력발전 해외수출의 생산유발효과, 부가가치 유발효과, 취업유발효과는 각각 28,525 억 원, 9,725 억원, 14,761 명으로 분석되었다.

주요어 : 석탄화력발전, 경제적 파급효과, 산업연관분석, 수요유도형 모형, 외생화

\begin{abstract}
Korean domestic electricity market is saturated through trying to find ways to overcome the limitations of the domestic electricity industry with overseas electricity markets. Korean electricity industry in the overseas market in order to pursue continuous growth, competitive and aggressive investment in overseas market is promoting. This paper attempts to apply input-output analysis to estimate the role of coal thermal power plant sector exports national economy. More specifically, this study shows what national economy effect of production-inducing effect, value-added inducing effect, and employment-inducing effect are explored with demand-driven model. After define coal thermal power plant sector what small sized of Input-Output table 168 sectors among 17 sectors, this study pays particular and close attention to coal thermal power plant sector by taking the sector as exogenous specification and then investigating economic impacts of it. This study uses coal thermal power plant exportation case of Vietnam project, production-inducing effect, value-added inducing effect, and employment-inducing effect are 2,853 billion won, 973 billion won and 14,761 persons, respectively.
\end{abstract}

Key words : oal thermal power plant, economic effect, input-output analysis, demand-driven model, exogenous specification

\footnotetext{
${ }^{\dagger}$ To whom corresponding should be addressed.

Graduate School of Energy and Environment, Seoul National

University of Science \& Technology. 232 Gongreung-Ro,

Nowon-Gu, Seoul, 139-743, Republic of Korea

Tel : 02-970-6802 E-mail : shyoo@seoultech.ac.kr
}

1. 서 론

21세기에 접어들면서 신자유주의 체제와 FTA는 
국가 간의 경제장벽을 빠르게 허물어 보호무역이나 관세장벽으로 국내 산업을 보호할 수 있는 명분이 사 라져 가고 있다. 따라서 이제는 모든 산업이 해외시 장에 나아가 경쟁해야 하는 현실에 직면하고 있다. 전력산업 또한 예외가 될 수 없으며, $\mathrm{KEPCO}$ 역시 해외시장에서 굴지의 전력회사들과의 경쟁을 피해갈 수 없게 되었다(대한전기협회, 2012). 국내 전력산업 은 국가경제 성장과 더불어 매년 $10 \%$ 이상 증가하는 전력수요를 기반으로 눈부신 성장을 지속해 왔다. 이 렇게 성장해 온 국내 전력시장의 수요 성장세는 향후 국내 경제성장의 둔화, 인구 감소, 노령화 사회 진입, 서비스업 중심의 전력 저소비형 산업구조로 변화하여 급격히 하락하고 있으며, 전력 직거래, 구역전기사업 자 등 민간부문의 전력시장 참여를 촉진하는 제도가 확대되고 있어 민간사업자들이 전력판매시장을 상당 부분 잠식할 것으로 예상됨에 따라 국내 시장만으로 는 지속적인 성장을 담보할 수 없게 되었다. 이와 같 은 국내시장 포화로 해외시장 개척을 통해 국내 전력 산업의 한계를 극복하기 위한 방안을 모색하며 해외 전력시장에서 세계 굴지의 전력기업들과 경쟁할 수 있는 경쟁력을 갖추고 지속적인 성장을 추구하기 위 해서 해외사업에 적극적인 투자를 추진하게 되었다.

1993년 중국에서 처음 시작한 $\mathrm{KEPCO}$ 의 전력산 업 해외진출은 과거 화력발전사업 위주의 사업영역에 서 원자력, 자원개발, 신재생, 송변전, 배전사업, 수력 등의 분야까지 다양화하며 확대하고 있다. 2011년 말 기준, 발전, 자원개발, 송변전 및 배전사업에서 운영 사업 24 개, 진행사업 14 개, 검토사업 56 개로 총 94 개 의 사업이 추진되고 있다. 또한, $\mathrm{KEPCO}$ 는 원자력 및 화력 발전소 건설, 자원개발 이외에도 송배전 설비 건설, 운영, 컨설팅 사업 등으로도 활발하게 확장하고 있고, 경제성장 과정에서 전력산업 분야에서 가지게 된 노하우를 주요 개발도상국과 공유하고 전수할 수 있는 해외인력 교육 및 주요 기관과의 $\mathrm{MOU}$ 체결도 확대하고 있다.

2012년 2월 $\mathrm{KEPCO}$ 는 조직을 크게 국내부문과 해외부문으로 나누는 창사 이래 최대의 조직개편을 단행하였으며, 이를 통해 $9 \cdot 15$ 순환정전사태 재발을 방지하고, 수익성 높은 해외사업을 확대하기 위해 전 력수급실을 신설하고 기술 엔지니어링 및 해외사업
개발을 집중 보강키로 하였다. 특히, 풍력발전을 포함 한 신재생에너지 사업을 확대하고, 인수합병과 플랜 트 수주를 통해 공격적으로 해외시장을 공략하기 위 해 해외사업전략실을 신설하였다. $\mathrm{KEPCO}$ 의 공격적 전력산업 해외진출은 고부가가치라는 사업의 특성상 전·후방 관련 산업의 해외진출 교두보 역할을 수행하 여 해외시장 개척에 상승효과를 가져올 것으로 기대 하고 있으며 이를 통한 부가가치 창출 및 수출증대 효과는 국가경제에도 큰 도움을 줄 것으로 예상되고 있다(진세준 외, 2012).

우리나라의 석탄화력발전 기술수준은 선진국과 동등한 수준이고, 일부 기술수준은 국산화가 되었다. 또한, 정부는 한국형 $300 \mathrm{MW}$ 급 IGCC1) 실증플랜트 기술개발 사업 등을 통하여 고효율 청정석탄 이용기 술의 조기 상용화로 기후변화협약에 따른 이산화탄소 배출을 저감하고, 석유를 대체할 경제성과 환경성이 우수한 신에너지원 확보를 통해 에너지안보를 구축하 며, 장기적으로는 한국형 IGCC 시스템을 개발을 통 하여 수출 상품으로 육성에 박차를 가하고 있다.

석탄화력발전 관련 부문은 제법 많은 산업들을 포함하고 있어, 먼저 연구의 범위 설정을 위한 원칙 을 설정하고 연구대상인 석탄화력발전 관련 부문의 범위를 정립한다. 다음으로 석탄화력발전 관련 부문 의 경제적 파급효과 분석방법론 및 실증연구 결과를 제시하기 위하여 산업연관분석(input-output analysis) 중 수요유도형 모형을 이용한다. 석탄화력발전 관련 부문의 경제적 파급효과를 계량화하기 위해서는 석탄 화력발전 관련 부문뿐만 아니라 다른 모든 경제부문 을 미시적으로 파악하면서도 거시적인 상호관계도 관 찰할 수 있어야 하는데, 이를 위해서는 산업연관분석 의 적용이 매우 유용하다. 산업연관분석에서는 석탄 화력발전 관련 부문의 변동이 생산, 부가가치, 고용 등 국민경제 미치는 각종 파급효과를 산업부문별로 나누어서 분석할 수 있기 때문에 석탄화력발전 관련 부문의 파급효과에 대한 사전적 예측이 가능하다. Fig 1 과 같이 석탄화력발전 해외수출이 일어났을 때, 후방에서 주되게 생산이 늘어나는 부문을 석탄화력발 전 관련 부문이라 할 수 있다. 이러한 파급효과는 생 산유발의 관점, 부가가치 유발의 관점, 취업유발의 관 점이라는 3 개의 관점에서, 석탄화력발전 관련 부문을

1) 석탄가스화 복합발전(IGCC: Integrated gasification combined cycle): 연료인 석탄을 고온 · 고압의 가스화기에서 가스화 시켜 일산화탄소와 수소가 주성분인 합성가스를 만들어 정제공정을 거친 후 가스터빈 및 증기터빈을 구동하는 복합 사이클 발전기술 
구매

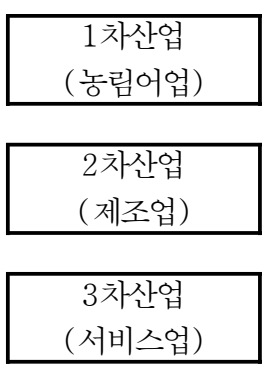

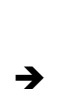

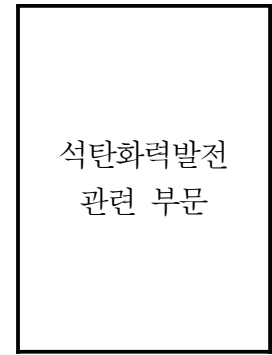

판매

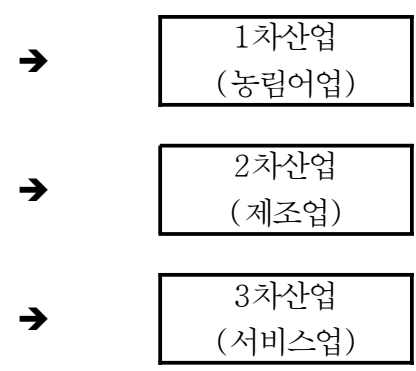

후방연쇄효과

전방연쇄효과

Fig. 1. Other Industrial Traction of Coal Thermal Power Plant Sector

외생화하여 자기산업 효과와 타 산업 효과로 구분하 여 결과를 도출한다.

이러한 배경 하에서 본 연구는 산업연관분석을 이용하여 석탄화력발전 해외수출이 국내경제에 미치 는 파급효과를 분석하고자 한다. 본 논문의 이후 구 성은 다음과 같다. 먼저 제 2 절에서는 석탄화력발전 관련 부문 정의에 대하여 살펴본다. 제 3 절에서는 연 구의 범위를 분명하게 설정하면서 국내경제에 미치는 경제적 파급효과 분석방법론인 산업연관분석의 수요 유도형 모형을 소개한 후, 이를 이용하여 석탄화력발 전 해외수출의 생산유발효과, 부가가치 유발효과, 취 업유발효과에 대한 분석결과를 제시한다. 마지막 절 에서는 연구의 결론으로 할애한다.

\section{2. 석탄화력발전 관련 부문의 정의}

\section{2-1 산업연관표상에서의 석탄화력발전 관련 부문}

본 연구에서는 석탄화력발전 관련 부문을 다음과 같이 정의한다. 석탄화력발전 해외수출이 일어났을 때, 국내에서 주로 생산이 늘어나는 부문을 석탄화력 발전 관련 부문으로 정의한다. 석탄화력발전관련 부 문의 범위를 설정하는 데 있어서, 한국은행에서 발표 된 산업연관표의 168 부문 통합소분류에 근거하여 석 탄화력발전 관련 부문의 유형을 정의한다.

석탄화력발전 관련 부문은 여러 산업 부문이 복합 적으로 포함되어 있어, $\mathrm{KEPCO}$ 및 석탄화력발전관련 부문 관계자에게 자문을 구하여 한국은행 산업연관표 168 부문 통합소분류에서 석탄화력발전 관련 부문과
관계가 있는 산업 부문을 도출하였다. 이에 따라 한 국은행 산업연관표 168 부문 통합소분류에 석탄화력 발전 관련 부문을 적용시켜 보았을 때, 관계가 있는 산업 부문 17 개 부문( 586 . 공구 및 철선제품」, 「88. 내연기관 및 터빈」, 「89. 일반목적용기계부 품」, 「90. 산업용운반기계」, 「91. 공조 및 냉온장 비」, 「92. 기타일반목적용기계」, 「95. 기타특수목 적용기계」, 「96. 발전기, 전동기 및 전기변환장치」, 「97. 기타전기장치」, 「106. 의료 및 측정기기」, $\lceil 126$. 교통시설건설」, 「127. 일반토목」, 「128. 기타특수건설」, 「138. 하역」, 「144. 금융」, $\ulcorner 150$. 사업관련서비스」, 「152. 건축 및 공학관련 서비스 )을 도출하여 석탄화력발전 관련 부문으로 설정하였다.

한국은행에서 발표된 2009년도 산업연관표상의 28 부문 통합대분류표를 기준으로 할 때, 석탄화력발전 관련 부문을 Table 1과 같이 45 부문으로 재구성할 수 있다.2) 본 연구에서는 이렇게 재구성된 산업연관표를 수요유도형 모형을 이용하여 생산유발효과, 부가가치 유발효과, 취업유발효과를 분석하되, 석탄화력발전 관련 부문을 각각 외생화한 분석, 즉 석탄화력발전 관련 부문을 중심에 놓고 다른 산업에 미치는 경제적 파급효과를 구한다.

2-2 석탄화력발전 해외수출 사례의 비용구조 분석 본 연구에서는 산업연관분석 중 수요유도형 모형 을 이용하여 생산유발효과, 부가가치 유발효과, 취업 유발효과의 결과를 도출한다. 하지만 분석결과는 단

2) 특정 관심대상 부문을 중심으로 한 논의를 위해 특정 부문을 별도의 부문으로 다루는 것은 산업연관분석에서 흔히 취하 는 접근 방식이다(한국은행, 1987). 
Table. 1. Sector Classification Adopted in This Study

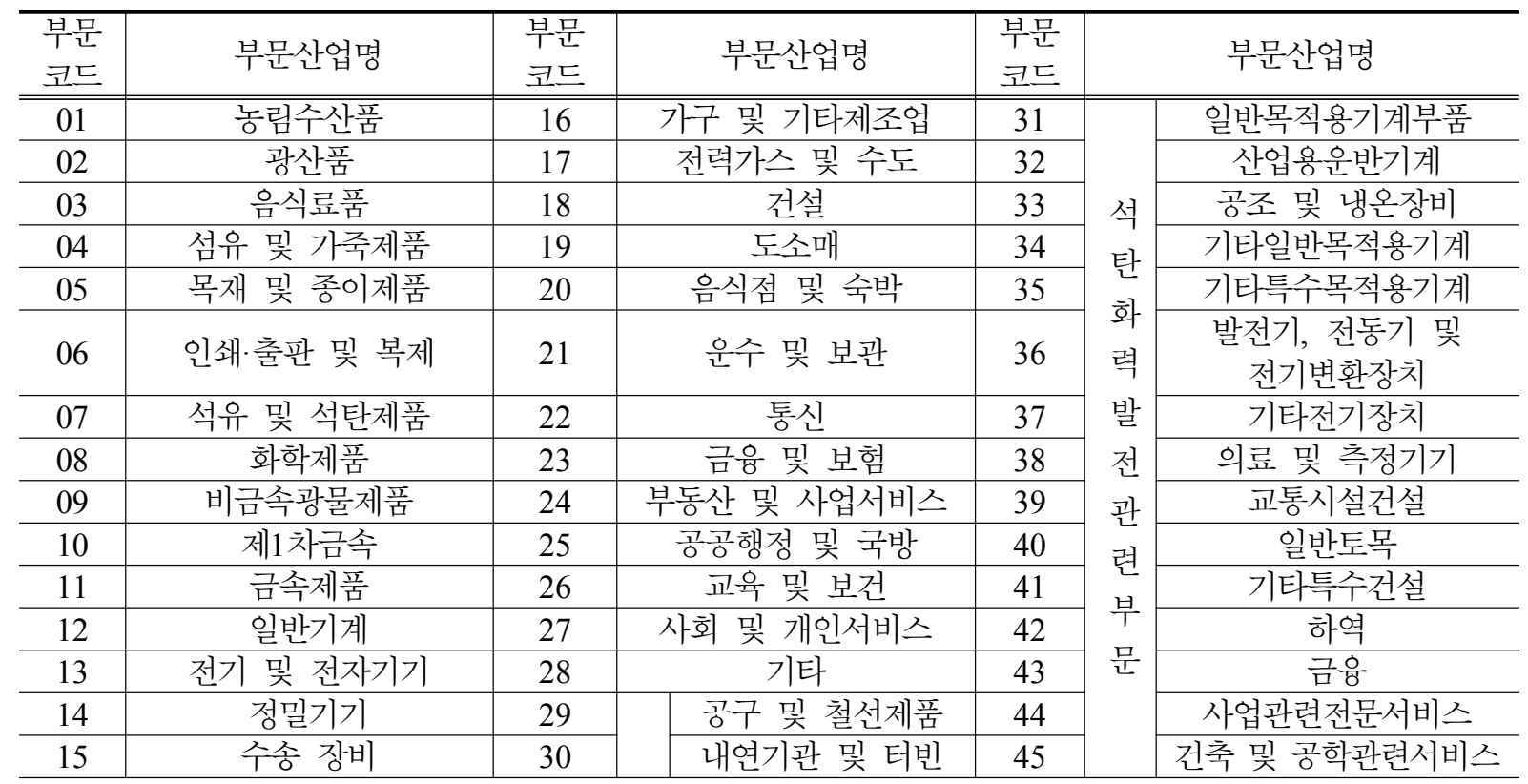

Table. 2. The Ratio of Coal Thermal Power Plant Exports and Matching with Sector Classification Adopted in This Study

\begin{tabular}{|c|c|c|c|}
\hline 공사세부내역 & $\begin{array}{c}\text { 재구성된 } \\
\text { 부문분류표 } \\
\text { 부문코드 } \\
\end{array}$ & 부문산업명 & $\begin{array}{c}\text { 석탄화력발전 해외수출 } \\
\text { 사례의 사업비 배분 비율 } \\
\text { (단위: } \%)\end{array}$ \\
\hline 보일러 & 33 & 공조 및 냉온장비 & 16.71 \\
\hline 터빈/발전기 & 30 & 내연기관 및 터빈 & 7.34 \\
\hline 탈황설비 및 탈질설비 & 34 & 기타일반목적용기계 & 7.77 \\
\hline \multirow{9}{*}{ 보조기기 } & 29 & 공구 및 철선제품 & 0.05 \\
\hline & 31 & 일반목적용기계부품 & 1.75 \\
\hline & 32 & 산업용 운반기계 & 0.22 \\
\hline & 33 & 공조 및 냉온장비 & 2.21 \\
\hline & 34 & 기타일반목적용기계 & 5.89 \\
\hline & 35 & 기타특수목적용기계 & 5.77 \\
\hline & 36 & 발전기, 전공기 및 전기변환장치 & 0.88 \\
\hline & 37 & 기타전기장치 & 1.53 \\
\hline & 38 & 의료 및 측정기기 & 0.13 \\
\hline 기계공사비 & 41 & 기타특수건설 & 4.80 \\
\hline 전기/계측공사비 & 41 & 기타특수건설 & 3.86 \\
\hline 토목공사비 & 40 & 일반토목 & 11.13 \\
\hline 건축공사비 & 41 & 기타특수건설 & 6.20 \\
\hline 부대공사비 & 39 & 교통시설건설 & 4.24 \\
\hline 설계용역비 & 45 & 건축 및 공학관련서비스 & 2.83 \\
\hline 사업주제경비 & 44 & 사업관련전문서비스 & 3.62 \\
\hline 수송/관세등 & 42 & 하역 & 1.96 \\
\hline 예비비 & 44 & 사업관련전문서비스 & 2.41 \\
\hline 건설이자 & 43 & 금융 & 8.68 \\
\hline \multicolumn{3}{|c|}{ 합 계 } & 100 \\
\hline
\end{tabular}


위당 파급효과이므로 석탄화력발전 해외수출 사례를 이용하여 분석 결과를 확장할 필요가 있다.

석탄화력발전 해외수출 사례를 이용하기 앞서, 현 재 국내 석탄화력발전 해외수출은 활발히 이루어지고 있는 상황이며, 인도네시아 찌레본 석탄화력발전소의 경우 국내 표준 석탄화력발전기술 해외전파라는 점에 서 큰 의미가 있다. 전술한 바와 같이, 정부의 기후변 화협약과 관련하여 고효율 청정석탄 개발 및 플랜트 기술개발에 박차를 가하고 있으며, 중동 및 동남아시 아 국가들과 중남미 국가들에서도 우리나라 석탄화력 발전에 큰 관심을 보이고 있다.

본 연구의 연구대상으로 정의한 석탄화력발전 관 련 부문의 해외수출은 과거 베트남 석탄화력발전 해 외수출의 견적서 세부구성을 따르고 있으며, 보수적 인 접근에서 $50 \%$ 만을 적용한 14,425 억원 규모의 석 탄화력발전 해외수출이 일어났을 경우로 가정한다. 그리고 사업비용의 국내집행율과 현지집행율을 구분 하여 비용을 배분하여야 하지만, 국내집행율과 현지 집행율을 구분하기에 어려움이 따르기에 본 연구에서 는 석탄화력발전 해외수출 견적서에 제시된 사업비용 $100 \%$ 가 국내에서 집행된다고 가정한다.

앞서 산업연관표를 재구성 하였듯이, 석탄화력발 전 해외수출 사례에 대한 사업비용의 산업분류 및 비 율 배분은 $\mathrm{KEPCO}$ 와 석탄화력발전 관련 부문 산업 에 종사하는 전문가들에게 자문을 구하여 분류하였 다. 석탄화력발전 해외수출 사례에 포함되는 세부 산 업분류 및 비율 배분과 앞서 본 연구에서 재구성한 산업연관표상의 부문 매칭을 Table 2에 제시하였다. 본 연구에서 석탄화력발전 해외수출 사례의 비용점유 율을 살펴보면, 보일러(공조 및 냉온장비)가 $16.71 \%$ 로 가장 크게 나타났다.

\section{3. 석탄화력발전 해외수출이 국내 경제에 미치는 파급효과 분석}

\section{3-1 산업연관분석의 개요}

본 연구의 목적은 석탄화력발전 해외수출이 타 산 업에 유기적으로 미치는 국내 경제에 미치는 산업파 급효과를 계량화하는 것이다. 이를 위해서는 석탄화 력발전 해외수출뿐만 아니라 다른 모든 경제부문을 미시적으로 파악하면서도 거시적인 상호관계도 관찰 하여야 한다. 이 목적을 달성하기 위해, 본 연구에서 는 산업연관분석을 적용한다. 산업연관분석이란 생산
활동을 통하여 이루어지는 산업간 상호연관관계를 수 량적으로 파악하는 분석방법으로, 국민경제 전체를 포괄하면서 전체와 부분을 유기적으로 결합한다 (Ghosh, 1958). 따라서 산업연관분석은 거시적 분석 이 미치지 못하는 산업과 산업간의 연관관계까지도 분석이 가능하기 때문에 구체적인 경제구조를 분석하 는데 유리하다(강광하, 2002; Bulmer-Thomas, 1982; Miller et al., 1989; Wu and Chen, 1990).

석탄화력발전 관련 부문을 중심으로 살펴보기 위 해서는 최종수요 변동에 초점을 맞추는 통상적 접근 법을 취해서는 안 된다. 왜냐하면 최종수요는 총수요 가 아니며 총수요라 하더라도 시장에서의 총공급과 일치해야만 명확한 의미를 갖는다. 그러므로 좀 더 엄밀한 의미에서 석탄화력발전 관련 부문의 경제적 영향력을 고찰하기 위해서는 석탄화력발전 관련 부문 의 총산출 변동에 초점을 맞추어야 한다. 또한 통상 적인 분석으로는 석탄화력발전 관련 부문 변동시 자 기 부문 외의 다른 부문들이 받는 영향만을 고찰할 수 없다. 이에 따라 석탄화력발전 관련 부문의 최종 수요가 증가하면, 석탄화력발전 관련 부문의 산출물 이 크게 증가하는 것으로 분석되는데 이는 논리적으 로 문제가 있다(유승훈 외, 2004).

이러한 문제점들은 관심대상 부문의 외생화 (exogenous specification)를 통해 해결이 가능하다. 경제에서 한 부문의 변화는 곧 그 경제 모형에 외생 적인 힘으로 작용한다. 산업연관분석에서는 이렇게 내생변수와 외생변수가 혼합되어 있는 경우, 외생적 인 힘이 될 변수를 외생화라고 한다(Miller and Blair, 1985). 이런 외생화의 방법을 쓰게 되면 총수요가 아 닌 특정부문의 산출물이 미치는 영향과 그 산출물이 타 산업에 유발하는 효과를 보다 명확히 알 수 있다. 석탄화력발전 관련 부문은 국내 경제의 기초산업 부문으로서 생산활동을 위해서는 여러 부문의 산출활 동을 필요로 한다. 즉 다른 부문들의 산출물을 중간 재로 수요한다. 따라서 석탄화력발전 해외수출 부문 의 투자가 타 부문에 미치는 파급효과가 클 수 있다. 이 파급효과는 생산유발의 관점, 부가가치 유발의 관 점, 취업유발의 관점이라는 3 개 관점에서 살펴 볼 수 있다.

\section{3-2 생산유발효과}

일반적으로 수요유도형(demand-driven model) 모 형에서 분석대상인 석탄화력발전 관련 부문(이하 $K$ 
부문)을 외생화하여 생산유발효과를 식으로 정리하면 다음과 같다.3)

$$
\Delta X^{e}=\left(I-A^{e}\right)^{-1}\left(A_{K}^{e} \Delta X_{K}\right)
$$

여기서, $\Delta X^{e}$ 는 분석대상인 석탄화력발전 관련 부 문을 제외한 다른 부문의 산출량으로서 석탄화력발전 관련 부문의 산출에 영향을 받은 타 부문의 산출 증 감량을 나타낸다. $\left(I-A^{e}\right)^{-1}$ 는 투입계수행렬에서 석 탄화력발전 관련 부문이 포함된 열과 행을 제외시켜 작성한 레온티에프 역행렬을 나타낸다. $A_{K}^{e}$ 는 투입 계수행렬로서 $A$ 에서 석탄화력발전 관련 부문을 나타 내는 열벡터 중에서 석탄화력발전 관련 부문 원소를 제외한 열벡터이며, $X_{K}$ 는 석탄화력발전 관련 부문의 산출액을 나타낸다.

식(1)은 관심대상인 석탄화력발전 관련 부문을 중 심으로 한 생산유발효과를 나타내는 식으로서 석탄화 력발전 관련 부문의 산출이 경제 내 다른 부문의 산 출에 미치는 직.간접적인 효과를 나타낸다. 또한 석탄 화력발전 관련 부문에 대한 투자는 자체로서의 산출 효과에 그치는 것이 아니라 연관효과를 통해 타 산업 부문의 생산을 유발시켜 결과적으로 전체 산업의 생 산을 촉진하므로, 식(1)로부터 석탄화력발전 관련 부 문의 총 산출 또는 총 투자로 인한 파급효과를 구할 수 있다.

\section{3-3 부가가치 유발효과}

최종수요의 발생이 국내생산을 유발하고 생산활동 에 의해서 부가가치가 창출되므로 결과적으로 최종수 요의 발생이 부가가치 창출의 원천이라고 할 수 있다. 부가가치 유발효과는 최종수요 한 단위 변화가 부가 가치 부문에 미치는 파급효과를 나타낸 것이다. 여기 서 석탄화력발전산업 부문의 산출액 증가가 타 부문 에 미치는 부가가치 유발효과를 관찰하기 위해, 최종 수요의 변동이 없다는 가정 하에 석탄화력발전 관련 부문을 외생화하면 다음 식이 유도된다.

$$
\Delta W^{e}=\widehat{A_{v}^{e}} \Delta X^{e}=\widehat{A_{v}^{e}}\left(I-A^{e}\right)^{-1}\left(A_{H}^{e} \Delta X_{H}\right)
$$

$\widehat{A_{v}^{e}}$ 은 부가가치계수의 대각행렬에서 석탄화력발전 관련 부문의 행과 열을 제외시키고 남은 행렬을 의미 한다. 식(2)를 통해 석탄화력발전 관련 부문의 산출액 증가에 따른 부가가치 유발효과를 구할 수 있다.

\section{3-4 취업유발효과}

최종수요는 생산을 유발시키고 생산은 다시 노동 수요를 유발한다. 그러므로 최종수요와 노동수요 유 발을 연결시킴으로써 취업유발효과를 구할 수 있다. 이를 위해서는 취업계수와 생산유발계수를 기초로 취 업유발계수를 도출해야 한다. 취업계수 $\left(n_{i}\right)$ 란 일정기 간 동안 생산활동에 투입된 노동량 $\left(N_{i}\right)$ 을 총산출액 $\left(X_{i}\right)$ 으로 나눈 계수 $\left(n_{i}=N_{i} / X_{i}\right)$ 로서 한 단위의 생 산에 직접 소요된 노동량을 의미한다. 투입된 노동량 $\left(N_{i}\right)$ 는 산업연관표 상 부속표에 포함된 고용표를 참 조하였다. 여기서 석탄화력발전 관련 부문을 외생화 하면 식(3)과 같이 표현된다.

$\Delta N^{e}=\widehat{n^{e}} \Delta X^{e}=\widehat{n^{e}}\left(I-A^{e}\right)^{-1}\left(A_{H}^{e} \Delta X_{H}\right)$

여기서 $N^{e}$ 는 석탄화력발전 관련 부문을 제외한 각 부문별 취업자수를 나타내며 $\Delta N^{e}$ 는 그 변동량을 의미한다. $\widehat{n^{e}}$ 는 취업계수 대각행렬에서 석탄화력발 전산업 부문의 행과 열을 제외시키고 남은 행렬이다.

\section{3-5 분석결과}

본 연구에서 사용한 자료는 한국은행에서 발표한 2009년 산업연관표이다. 석탄화력발전 관련의 생산 유발효과를 분석한 결과를 살펴보면, Table 3 과 같이

「29. 공구 및 철선제품」의 경우 생산유발효과가 가 장 크며, 「41. 기타특수건설」, 「33. 공조 및 냉온 장비」 순으로 생산유발효과가 크다. 이것은 석탄화력 발전기 건설과정에서 공구 및 철선제품 부문이 가장 많이 이용되며, 기타특수건 부문과 공조 및 냉온장비 부문의 산출물도 많이 활용되기 때문인 것으로 판단 된다.

타 산업 효과 중심으로 부가가치 유발효과를 분석 한 결과를 살펴보면, Table 4에서와 같이 「41. 기타 특수건설」 의 경우 부가가치 유발효과가 가장 크며,

3) 이 식의 자세한 유도과정에 대해서는 유승훈(2003) 및 Yoo and Yang(1999) 등을 참고할 수 있다. 
Table. 3. Production-inducing Effect of Coal Thermal Power Plant Sector

\begin{tabular}{c|l|c|c|c}
\hline \multirow{2}{*}{ 부문코드 } & \multirow{2}{*}{ 부문산업명 } & \multicolumn{2}{|c}{ 1원 수출의 생산유발효과 (단위: 원) } \\
\cline { 3 - 5 } & & 자기산업 효과 & 타 산업 효과 & 총 효과 \\
\hline \hline 29 & 공구 및 철선제품 & 1.0000 & 1.4083 & 2.4083 \\
\hline 30 & 내연기관 및 터빈 & 1.0000 & 1.0446 & 2.0446 \\
\hline 31 & 일반목적용기계 & 1.0000 & 1.1316 & 2.1316 \\
\hline 32 & 산업용운반기계 & 1.0000 & 1.0372 & 2.0372 \\
\hline 33 & 공조 및 냉온장비 & 1.0000 & 1.1007 & 2.1007 \\
\hline 34 & 기타일반목적용기계 & 1.0000 & 1.0783 & 2.0783 \\
\hline 35 & 기타특수목적용기계 & 1.0000 & 1.0071 & 2.0071 \\
\hline 36 & 발전기,전동기 및 전기변환장치 & 1.0000 & 1.0531 & 2.0531 \\
\hline 37 & 기타전기장치 & 1.0000 & 0.8133 & 1.8133 \\
\hline 38 & 의료 및 측정기기 & 1.0000 & 0.9637 & 1.9637 \\
\hline 39 & 교통시설건설 & 1.0000 & 1.1917 & 2.1917 \\
\hline 40 & 일반토목 & 1.0000 & 1.0846 & 2.0846 \\
\hline 41 & 기타특수건설 & 1.0000 & 1.3405 & 2.3405 \\
\hline 42 & 하역 & 1.0000 & 0.9466 & 1.9466 \\
\hline 43 & 금융 & 1.0000 & 0.3953 & 1.3953 \\
\hline 44 & 사업관련전문서비스 & 1.0000 & 0.4725 & 1.4725 \\
\hline 45 & 건축 및 공학관련서비스 & 1.0000 & 0.5062 & 1.5062 \\
\hline
\end{tabular}

Table. 4. Value-added Inducing Effect of Coal Thermal Power Plant Sector

\begin{tabular}{c|l|c|c|c}
\hline \multirow{2}{*}{ 부문코드 } & \multicolumn{1}{|c|}{ 부문산업명 } & \multicolumn{3}{|c}{ 1원 수출의 생산유발효과 (단위: 원) } \\
\cline { 3 - 5 } & & 자기산업 효과 & 타 산업 효과 & 총 효과 \\
\hline \hline 29 & 공구 및 철선제품 & 0.2727 & 0.3426 & 0.6154 \\
\hline 30 & 내연기관 및 터빈 & 0.2252 & 0.3216 & 0.5468 \\
\hline 31 & 일반목적용기계 & 0.3398 & 0.3205 & 0.6603 \\
\hline 32 & 산업용운반기계 & 0.2605 & 0.3136 & 0.5741 \\
\hline 33 & 공조 및 냉온장비 & 0.2551 & 0.3219 & 0.5770 \\
\hline 34 & 기타일반목적용기계 & 0.2702 & 0.3102 & 0.5804 \\
\hline 35 & 기타특수목적용기계 & 0.2648 & 0.2946 & 0.5594 \\
\hline 36 & 발전기,전동기 및 전기변환장치 & 0.2862 & 0.3249 & 0.6111 \\
\hline 37 & 기타전기장치 & 0.2639 & 0.2503 & 0.5142 \\
\hline 38 & 의료 및 측정기기 & 0.2837 & 0.3313 & 0.6150 \\
\hline 39 & 교통시설건설 & 0.3981 & 0.3641 & 0.7622 \\
\hline 40 & 일반토목 & 0.4413 & 0.3354 & 0.7767 \\
\hline 41 & 기타특수건설 & 0.3381 & 0.4034 & 0.7415 \\
\hline 42 & 하역 & 0.4409 & 0.3613 & 0.8022 \\
\hline 43 & 금융 & 0.6134 & 0.1909 & 0.8042 \\
\hline 44 & 사업관련전문서비스 & 0.7248 & 0.1924 & 0.9172 \\
\hline 45 & 건축 및 공학관련서비스 & 0.6742 & 0.1996 & 0.8738 \\
\hline
\end{tabular}

「42.하역」이 두 번째 「29. 공구 및 철선제품」이 세 번째로 크다. 국민경제 전체적으로 부가가치 유발 효과를 분석한 결과를 살펴보면, 「44. 사업관련전문 서비스」의 경우 부가가치 유발효과가 가장 크며, 다 음으로 「43. 금융」, 「42.하역」 순이다. 사업관련전
문서비스 부문의 경우 공공관계서비스가 포함되어 있 어 큰 부가가치를 유발하는 것으로 판단되며, 금융 부문의 경우도 석탄화력발전산업에 영향을 끼쳐 상대 적으로 많은 부가가치를 유발하는 것으로 판단된다. 타 산업 효과 중심으로 취업유발효과를 분석한 결 
Table. 5. Employment-inducing Effect of Coal Thermal Power Plant Sector

\begin{tabular}{c|c|c|c|c}
\hline \multirow{2}{*}{ 부문코드 } & \multicolumn{2}{|c|}{ 부문산업명 } & \multicolumn{3}{|c}{10 엉원 수출의 생산유발효과 (단위: 명/10억원) } \\
\cline { 3 - 5 } & 강기산업 효과 & 타 산업 효과 & 총 효과 \\
\hline \hline 29 & 철선제품 & 3.4974 & 5.0659 & 8.5633 \\
\hline 30 & 내연기관 및 터빈 & 1.4602 & 5.2707 & 6.7309 \\
\hline 31 & 일반목적용기계 & 4.4636 & 5.4333 & 9.8969 \\
\hline 32 & 산업용운반기계 & 2.7111 & 5.1776 & 7.8887 \\
\hline 33 & 공조 및 냉온장비 & 3.7553 & 5.5313 & 9.2866 \\
\hline 34 & 기타일반목적용기계 & 3.8646 & 5.2164 & 9.0810 \\
\hline 35 & 기타특수목적용기계 & 5.2594 & 4.8222 & 10.0816 \\
\hline 36 & 발전기,전동기 및 전기변환장치 & 2.4695 & 5.4985 & 7.9680 \\
\hline 37 & 기타전기장치 & 3.4094 & 4.2804 & 7.6898 \\
\hline 38 & 의료 및 측정기기 & 6.3655 & 5.7328 & 12.0983 \\
\hline 39 & 교통시설건설 & 6.5192 & 5.6042 & 12.1234 \\
\hline 40 & 일반토목 & 6.6227 & 5.2557 & 11.8783 \\
\hline 41 & 기타특수건설 & 7.1959 & 6.4171 & 13.6130 \\
\hline 42 & 하역 & 6.9714 & 6.4190 & 13.3904 \\
\hline 43 & 금융 & 3.6363 & 2.9095 & 6.5457 \\
\hline 44 & 사업관련전문서비스 & 9.2924 & 3.5002 & 12.7926 \\
\hline 45 & 건축 및 공학관련서비스 & 11.2533 & 3.8584 & 15.1117 \\
\hline
\end{tabular}

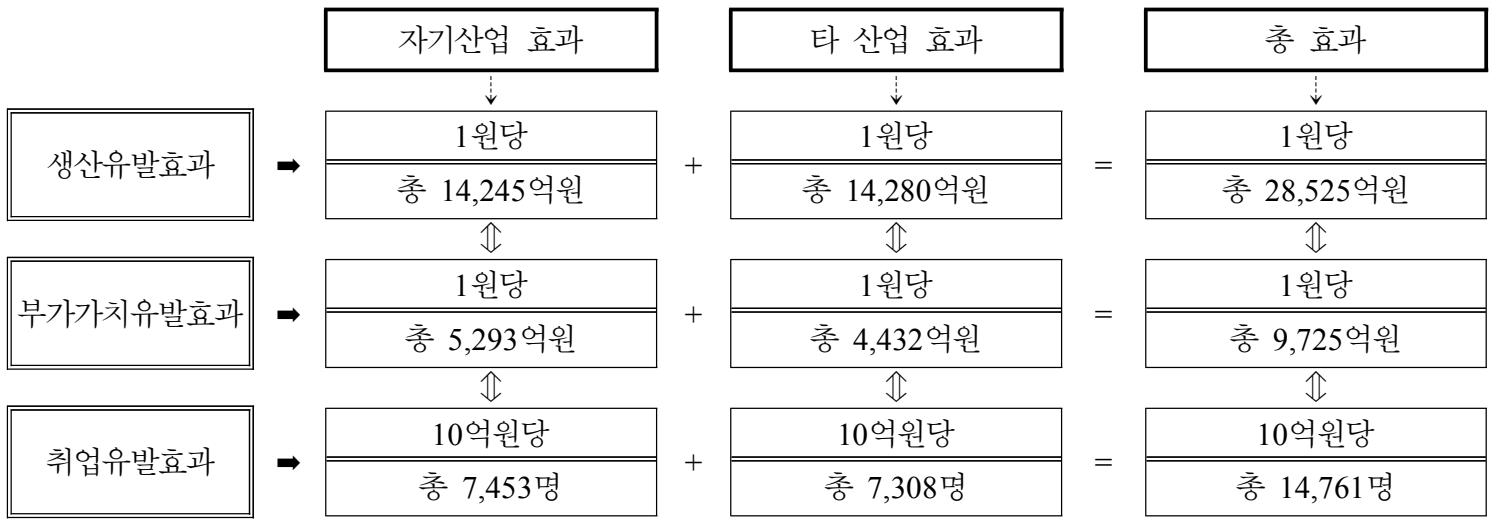

Fig. 2. Forecasting Results of the Economic Effects of Coal Thermal Power PlantExports

과를 살펴보면, 「42. 하역」,「41. 기타특수건설」, 「38. 의료 및 측정기기」 의 순으로 취업유발효과가 크게 분석되었다. 국민경제 전체적으로 취업유발효과 를 분석한 결과를 살펴보면, 「45. 건축 및 공학관련 서비스 의 경우 취업유발효과가 가장 크며, 다음으 로 「41. 기타특수건설」 이 두 번째로, 「36. 하역」 이 세 번째로 큰 것을 Table 5 에서 확인할 수 있다. 결과에서 보여지듯이 석탄화력발전산업의 경우 노동 집약적인 기타특수건설과 하역 부문에서 많은 취업이 유발되는 것으로 판단된다.

에너지공학 제22권 제1호 2013
3-6 석탄화력발전 해외수출의 사례 적용

본 연구에서 분석한 결과는 단위당 파급효과이므 로 석탄화력발전 해외수출 사례의 사업비를 투입하여 확장할 필요가 있다. 따라서 제 2 절에서 전술한 바와 같이, 석탄화력발전 해외수출 사례는 석탄화력발전 관련 부문 관계자의 해외수출 견적서 세부구성을 따 르고 있으며, 과거 베트남 수출 사례의 14,245억원 규모의 석탄화력발전 해외수출이 일어났을 경우로 가 정한다. 그리고 사업비용의 국내집행율과 현지집행율 을 구분하여 비용을 배분하여야 하지만, 국내집행율 과 현지집행율을 구분하기에 어려움이 있다. 따라서 
본 연구에서는 석탄화력발전 해외수출 견적서에 제시 된 사업비용 $100 \%$ 가 국내에서 집행된다고 가정한다. 석탄화력발전 해외수출로 14,245 억원의 사업비를 수 주하였다고 가정한 후, 앞서 구한 결과에 적용하여 국내 경제에 석탄화력발전 해외수출이 미치는 파급효 과를 예상할 수 있다. 석탄화력발전 해외수출로 수주 한 사업비에 근거하여 각 파급효과를 계산한 결과의 요약 및 종합화를 Fig 2에 제시하였다.

석탄화력발전 해외수출에 미치는 생산유발효과가 1.0 임을 감안할 때, 석탄화력발전 해외수출로 인한 1 원 생산증가로 발생한는 총 생산유발효과에 수주된 사업비 14,245 억원을 대입하면, 석탄화력발전 해외수 출의 자기산업 효과 14,245 억원과 타 산업 효과 14,280 억원을 합하여 총 28,525 억원의 생산유발효과 를 가져올 것으로 예상된다. 석탄화력발전 해외수출 의 1 원 생산증가로 인한 총 부가가치 유발효과는 석 탄화력발전 해외수출의 자기산업 부가가치 유발효과 5,293 억원 및 타 산업 부가가치 유발효과 4,432억원 을 합하여 총 9,725 억원의 부가가치 유발효과를 가져 올 것으로 예상된다. 석탄화력발전 해외수출에서의 총산출 10 억원 생산증가로 인한 석탄화력발전 해외 수출의 자기산업 취업유발효과 7,453명과 타 산업 취 업유발효과 7,308명을 합하여 총 14,761 명의 취업이 유발될 것으로 예상된다.

\section{4. 결 론}

$\mathrm{KEPCO}$ 는 해외시장 개척을 통해 국내 전력산업의 한계를 극복하기 위한 방안을 모색하고 있다. 해외 전력시장에서 세계 굴지의 전력기업들과 경쟁할 수 있는 경쟁력을 갖추고 지속적인 성장을 추구하기 위 해서 2012년 2월 조직을 크게 국내부문과 해외부문 으로 나누는 조직개편을 단행하는 등 해외사업에 적 극적인 투자를 추진 중에 있다. 해외 전력시장은 과 거 국영, 독점체제의 틀에서 벗어나 규제완화 및 민 영화로 표방되는 새로운 전력산업으로 패러다임이 바 뀌고 있다. 또한 국제에너지기구(IEA)의 발표에 따르 면 전 세계의 전력소비 규모는 2030년까지 현재보다 총 $40 \%$ 가 증가하며, $\mathrm{OECD}$ 국가와 비 $\mathrm{OECD}$ 국가 간 전력생산 비중이 역전될 것으로 전망하고 있다. 따라 서 해외 전력시장에서 세계 굴지의 전력기업들과 경 쟁할 수 있는 경쟁력을 갖추고, 지속적인 성장을 추 구하기 위해서는 해외시장에 적극적인 투자와 함께
추진여건을 개선해 나가야 한다. 전력산업의 해외진 출은 고부가가치의 종합 플랜트산업이라는 사업특성 상 전·후방 관련 산업의 해외진출 교두보 역할을 수 행하며, 해외 수익창출을 통한 경영효율 증대를 가져 온다. 건설, 기자재산업 등 전력사업 수행에 필수적인 유관 산업은 해외시장 개척의 동반자이자 조력자로서 상호협력에 따른 상승효과를 기대할 수 있으며, 이를 통한 고부가가치 창출은 국가경제에도 큰 도움을 준 다. 또한, 전력산업의 해외진출은 국내 전력산업의 공 익성 증진에 크게 기여할 수 있으며, 이를 통해 창출 된 해외수익은 장기적으로 국내 전력요금 인하 및 설 비 확충의 재원이 되어 국내 공익 증진에 크게 기여 할 수 있다. 이는 전력산업의 공익성을 훼손시키지 않고 경영 효율성을 제고할 수 있다는 점에서 한전의 지속적인 성장을 위한 중요한 요소로 인식되고 있다. 이와 함께 전력산업은 국가 에너지정책에 큰 부분을 차지하는 국가 기간산업으로 해외진출 시 국가 간 타 분야 경제협력의 계기가 될 수 있다. 이를 통해 타 산 업과의 협력증진은 물론 국가 간의 협력이 한층 활발 해질 것으로 예상된다(대한전기협회, 2012). 이에 본 연구에서는 석탄화력발전 해외수출의 경제적 파급효 과를 정량적으로 평가하고자 하였다.

석탄화력발전을 연구대상으로 설정하기에는 그 연 구 범위가 모호하므로, 먼저 연구의 대상을 석탄화력 발전 관련 부문으로 범위 설정을 위한 정의를 설정하 고 석탄화력발전 해외수출 견적서를 통한 과거 사례 를 이용하여 연구대상 석탄화력발전 관련 부문의 범 위를 제시하였다. 다음으로 석탄화력발전 관련 부문 의 경제적 파급효과 분석방법론 및 실증연구 결과를 제시하였다. 석탄화력발전 관련 부문의 경제적 파급 효과를 계량화하기 위해서는 석탄화력발전 관련 부문 뿐만 아니라 다른 모든 경제부문을 미시적으로 파악 하면서 거시적인 상호관계도 관찰할 수 있어야 하는 데, 이를 위해서는 산업연관분석의 적용이 매우 유용 하므로 산업연관분석을 이용하였다. 특히 산업연관분 석의 수요유도형 모형을 이용하여 석탄화력발전 관련 부문의 변동이 생산, 부가가치, 취업 등 국내 경제에 미치는 각종 파급효과를 산업부문별로 나우어서 분석 할 수 있기 때문에 석탄화력발전 관련 부문의 파급효 과에 대한 사전적 예측이 가능하다. 석탄화력발전 관 련 부문의 생산유발효과, 부가가치 유발효과, 취업유 발효과를 자기산업 효과와 타 산업 효과로 구분하여 구했다(진세준 외, 2012). 
석탄화력발전 베트남 해외수출 14,245 억원이 일어 날 경우, 생산유발효과, 부가가치 유발효과, 취업유발 효과는 각각 28,525 억원, 9,725 억원, 14,761 명으로 분석되었다. 이러한 정량적 정보는 석탄화력발전 해 외수출로 국내 경제에 미치는 파급효과의 기초자료로 활용될 수 있다. 예를 들어, 석탄화력발전 해외수출로 국내 경제에 미치는 파급효과를 사전적으로 예측함으 로써 석탄화력발전의 해외시장 진출시 중요한 참고자 료로 활용이 가능하다. 특히 석탄화력발전 관련 부문 이 한국은행 산업연관표상에 정의 되어있지 않으나, 실제 석탄화력발전 해외수출 견적서의 세부비용을 면 밀하게 파악해서 석탄화력발전 관련 부문을 정의하 고, 비용구조를 분석한 부분은 본 연구의 의의라 할 수 있다. 또한 석탄화력발전 해외수출 실제 사례의 비용구조 정보에 근거해서 경제적 파급효과를 구하므 로써 보다 엄밀하게 경제적 파급효과를 분석할 수 있 었다. 따라서 본 연구결과를 확정적인 값으로 받아들 이기보다는 경제적 파급효과에 대한 추정치 정도로 받아들이면서, 이러한 파급효과를 달성할 수 있도록 석탄화력발전 해외수출의 전략이 필요할 것이다.

투입산출분석은 비교적 적용이 간단하면서도 다양 한 정보를 제공하기에 연구자와 정책 결정가에게 유 용한 분석도구이다. 본 연구에서 제시된 투입산출분 석을 보다 확장할 수 있는 연구 주제로는 여러 연도 의 산업연관표를 동적으로 연결한 동적 분석, 석탁화 력발전 산업을 선진국 산업연관표에 근거한 국가간 비교분석, 그리고 더 나아가 산업연관표를 보다 최근 자료로의 업데이트하는 기법을 이용한 석탄화력발전 의 미래에 대한 예측 등을 들 수 있다. 앞으로 관련된 다양한 후속 연구가 수행되기를 기대한다.

$$
\text { 사 사 }
$$

이 연구는 서울과학기술대학교 교내 학술연구비 일부 지원으로 수행되었습니다.

\section{참고문헌}

1. 강광하 (2000), “산업연관분석론”, 연암사

2. 강기춘, 양상돈 (1999), “산업연관표를 이용한 전력 산업의 경제적 효과 분석”, 경제논집, 제 13 집 제 1 호, 제주대학교 관광산업연구소, pp. 437-455.

3. 곽소윤, 유승훈, 곽승준 (2008), "디지털 방송산업의 향후 전망과 경제적 파급효과 분석", 산업경제연구,
제 21 권, 제6호, 한국산업경제학회, pp. 2371-2388.

4. 곽승준, 유승훈, 한상용 (2002), “발전부문별 국민경 제적 파급효과 분석”, 자원·환경경제연구, 제 11 권, 제4호, 한국자원경제학회, pp.581-608

5. 대한전기협회 (2012), "2012 전기연감".

6. 손양훈, 정태용 (1993), “전력산업의 규모의 경제성 에 관한 연구", 경제학연구, 제 45 집 제 2 호, 한국경 제학회, pp.29-47.

7. 유승훈 (2003), “정보통신산업의 국민경제적 산업파 급효과 분석", Telecommunications Review, 제13 권, 제3호, SK Telecom, pp. 347-359.

8. 유승훈 (2007), “산업연관분석을 이용한 해양심층수 산업화의 국민경제적 파급효과 분석", 산업경제연 구, 제 20 권, 제4호, 한국산업경제학회, $\mathrm{pp}$. 1345-1357.

9. 유승훈, 양창영 (2007), "지상파 방송광고 단가 변동 의 경제적 파급효과", 광고연구, 제 75 권, 한국방송 공사, pp. 143-162.

10. 유승훈, 임응순, 구세주 (2008), “광고산업의 국민 경제적 산업파급효과 분석”, 광고연구, 제 78 권, 한 국방송공사, pp. 189-214.

11. 유승훈, 정동원, 박세헌 (2010)), "태평양 심해저 망간단괴 개발사업의 경제적 파급효과", Ocean and Polar Research, 제 32 권, 한국해양연구원, 제 4 호, pp. 489-499.

12. 유승훈, 허재용, 김기주 (2004), "투입산출표의 외 생화를 이용한 전파방송산업의 산업파급효과 분 석”, 산업경제연구, 제 17 권, 제 5 호, 한국산업경제학 회, pp. 1593-1612.

13. 진세준, 유승훈 (2012), “풍력발전 해외수출의 경 제적 파급효과 분석”, 에너지공학, 제 21 권, 제 3 호, 한국에너지공학회, pp. 311-321.

14. 한건택, 김혜민, 유승훈 (2012), "집단에너지산업 의 경제적 파급효과 분석", 에너지공학, 제 21 권, 제 1 호, 한국에너지공학회, pp. 47-54.

15. 허재용, 유승훈 (2009), "지식서비스산업의 경제적 파급효과 국가간 비교분석 : 한국, 미국, 일본, 영국 을 중심으로", 산업경제연구, 제 22 권 제 6 호, 한국산 업경제학회, pp. 3189-3208.

16. 에너지경제연구원 (2011), "에너지 수요전망".

17. 지식경제부 (2010), “제 5 차 전력수급 기본계획 (2010년 2024년)".

18. 한국은행 (2011), "2009년 산업연관표".

19. Bulmer-Thomas, V.(1982). Input-Output Analysis in Developing Countries. New York: Wiley.

20. Ciaschini, M.(1988). Input-Output Analysis. London: Chapman and Hall.

21. Ghosh, A.(1958). Input-output approach to an allocative system. Economica, 25, 58-64. 
22. Han, S. -Y., Yoo, S. -H., \& Kwak S. -J.(2004). The role of four electric power sectors in the Korean national economy: An input-output analysis, Energy Policy, 32, 1531-1543.

23. Kwak, S. -J., Yoo S. -H. and Chang J. -I.(2005), Role of maritime industry in the Korean National Economy: An Input-Output Analysis, Marine Policy, 29, 371-383.

24. Miller, R. E., \& Blair, P. D.(1985). Input-output Analysis: Foundations and Extensions. New Jersey: Prentice-Hall.

25. Miller, R. E., Polenske, K. R., and Rose, A. Z. (ed.)(1989), Frontiers of Input-Output Analysis. Oxford: Oxford University Press.

26. Wu, R. H., \& Chen, C. Y.(1990), On the application of input-output analysis to energy issues. Energy Economics, 12, 71-76.

27. Yoo S. -H., \& Yang C. -Y.(1999). Role of water utility in the Korean national economy. International Journal of Water Resources Dev. 